Jurnal Ekonomi Balance Fakultas Ekonomi Dan Bisnis

Volume 11 No 1 Tahun 2015

\title{
ANALISIS PENGARUH TENAGA KERJA, TINGKAT PENDIDIKAN DAN PENGELUARAN PEMERINTAH TERHADAP PERTUMBUHAN EKONOMI DI KOTA MAKASSAR TAHUN 2004-2013
}

\author{
H. Muh. Rusdi ${ }^{1}$ Haerati $^{2}$ \\ IImu Ekonomi Studi Pembangunan Fakultas Ekonomi Dan Bisnis \\ Universitas Muhammadiyah Makassar \\ (Rusdi@unismuh.ac.id)
}

\begin{abstract}
This study aims to determine and analyze how much influence the amount of labor, education and government spending on economic growth in the city of Makassar. The hypothesis is that the amount of labor, education level and government spending have a positive and significant impact on economic growth in Makassar. The type of data used in this study is secondary data. The data is then processed using a computer program that is SPSS 16 with multiple linear regression analysis method. The results showed that the number of labor force, education level and government expenditure had a positive effect on the economic growth in Makassar City, the regression result between dependent variable and independent variable was $R$-Square $=0,979$ and $F$ statistic $=93,880$ so that together variable of labor force, and government expenditure has a positive effect on economic growth in Makassar City.
\end{abstract}

Keywords: Economic Growth, Workforce, Education Level And Government Expenditure

\begin{abstract}
ABSTRAK
Penelitian ini bertujuan untuk mengetahui dan menganalisis seberapa besar pengaruh jumlah tenagakerja, tingkat pendidikan dan pengeluaran pemerintah terhadap pertumbuhan ekonomi di kota Makassar. Hipotesis yang diajukanya itu jumlah tenaga kerja, tingkat pendidikan dan pengeluaran pemerintah berpengaruh positif dan signifikan terhadap pertumbuhan ekonomi di Kota Makassar. Jenis data yang digunakan dalam penelitian ini adalah data sekunder. Data tersebut kemudian diolah dengan menggunakan program computer yakni SPSS 16 dengan metode analisis regresi linear berganda. Hasil penelitian menunjukkan bahwa jumlah tenagakerja, tingkat pendidikan dan pengeluaran pemerintah berpengaruh positif terhadap pertumbuhan ekonomi di Kota Makassar, hasil regresi antara variabel dependent dengan variabel independent adalah $\mathrm{R}$-Square $=0,979$ dan $\mathrm{F}$ statistik $=93,880$ sehingga secara bersamasama variabel tenagakerja, tingkat pendidikan dan pengeluaran pemerintah berpengaruh positif terhadap pertumbuhan ekonomi di Kota Makassar.
\end{abstract}

Kata Kunci: Pertumbuhan Ekonomi, TenagaKerja, Tingkat Pendidikan Dan PengeluaranPemerintah 
Jurnal Ekonomi Balance Fakultas Ekonomi Dan Bisnis

Volume 11 No 1 Tahun 2015

\section{PENDAHULUAN}

\section{Latar Belakang}

Tanpa pertumbuhan ekonomi maka pembangunan suatu negara tidak akan berjalan sebagaimana mestinya. Pertumbuhan ekonomi merupakan salah satu indikator keberhasilan pembangunan yang digunakan sebagai ukuran atas perkembangan atau kemajuan perekonomian dari suatu negara atau wilayah karena berkaitan erat dengan aktivitas kegiatan ekonomi masyarakat dalam hal peningkatan produksi barang dan jasa.Peningkatan dalam pertumbuhan ekonomi menjadi salah satu target pembangunan ekonomi baik ditingkat nasional maupun daerah.

Pertumbuhan ekonomi merupakan masalah suatu negara dalam jangka panjang. Prestasi pertumbuhan ekonomi diukur dari perkembangan suatu perekonomian dari suatu periode ke periode berikutnya dalam kemampuan suatu negara untuk menghasilkan barang dan jasa yang akan meningkat disebabkan oleh faktor-faktor produksi yang selalu mengalami pertambahan dalam jumlah dan kualitasnya. Menurut Sukirno (2011) perkembangan kemampuan memproduksi barang dan jasa sebagai akibat pertambahan faktor-faktor produksi pada umumnya tidak selalu diikuti oleh pertambahanproduksi barang dan jasa yang sama besarnya.Pertambahan potensi memproduksi kerap kali lebih besar dari pertambahan produksi yang sebenarnya. Dengan demikian perkembangan ekonomi adalah lebih lambat dari potensinya.

Suatu perekonomian dikatakan mengalami pertumbuhan ekonomi jika jumlah produksi barang dan jasa pada tahun tertentu lebih besar daripada tahun sebelumnya. Jika kenaikan produksi barang dan jasa pada tahun tertentu lebih tinggi dari tahun sebelumnya maka terjadi kenaikan pertumbuhan, sebaliknya jika terjadi penurunan produksi barang dan jasa dari tahun sebelumnya maka terjadi perlambatan pertumbuhan ekonomi. Indikator yang digunakan untuk mengukur pertumbuhan ekonomi ditingkat nasional adalah Produk Domestik Bruto (PDB), sedangkan untuk tingkat daerah digunakan Produk Domestik Regional Bruto (PDRB). Pertumbuhan ekonomi yang dicapai kota Makassar periode tahun 20042013 dengan rata-rata pertumbuhan 9,16 persen selama sepuluh tahun terakhir.

Pada tahun 2005 pertumbuhan ekonomi kota Makassar sebesar 7,22 persen sedikit melambat dibandingkan tahun sebelumnya, namun produk domestik regional bruto (PDRB) dari tahun ke tahun mengalami kenaikan yang 
Jurnal Ekonomi Balance Fakultas Ekonomi Dan Bisnis

Volume 11 No 1 Tahun 2015

semakin membaik.Pertumbuhan ekonomi kota Makassar dalam kurun 2004-2013 selalu yang tertinggi jika dibandingkan dengan dengan kabupaten/kota lain di Sulawesi selatan. Dengan kontribusi PDRB sebesar 33,18 persen tahun 2013 memberikan indikasi kuatnya pengaruh perekonomian kota Makassar terhadap perekonomian Sulawesi selatan. Kemajuan perekonomian yang dicapai kota Makassar dalam kurun waktu sepuluh tahun terakhir terus menunjukkan peningkatan dengan meningkatnya nilai produk domestik yang dihasilkan dari tahun ke tahun. Kenaikan nilai nominal PDRB atas dasar harga yang cukup signifikan dalam beberapa tahun terakhir di pengaruhi oleh adanya kenaikan produksi barang dan jasa dan juga kenaikan harga. Pada tahun 2013 nilai PDRB kota Makassar mencapai angka 58,80 triliun rupiah dibandingkan dengan lima tahun sebelumnya.

Perkembangan PDRB kota Makassar dalam kurun waktu sepuluh tahun tahun terakhir dari tahun 2004-2013 dengan rata-rata perkembangan sekitar 18,11 persen pertahun. Kontribusi kota Makassar terhadap besarnya PDRB Sulawesi selatan mencapai 31,82 persen pada tahun 2013. Hal ini berarti 31,82 persen perekonomian propinsi Sulawesi selatan berada di kota Makassar. Kontribusi kota Makassar terhadap pembentukan PDRB Sulawesi selatan mengalami penigkatan, yaitu pada tahun 2009 sebesar 31,28 persen meningkat menjadi 31,82 persen tahun 2013. Ini menunjukkan perkembangan perekonomian kota Makassar lebih cepat bila dibandingkan dengan kabupaten/kota lain di Sulawesi selatan.

Salah satu indikator penting dalam pertumbuhan ekonomi adalah sumber daya manusia yang ada disuatu wilayah. Pertumbuhan penduduk dan tenaga kerja secara tradisional dianggap sebagai faktor positif dan merangsang pertumbuhan ekonomi. Jumlah tenaga kerja yang lebih besar berarti akan meningkatkan luasnya pasar domestik. Pada dasarnya penduduk dapat dibagi menjadi dua kelompok yaitu penduduk yang termasuk dalam kelompok angkatan kerja dan bukan angkatan kerja. Penduduk yang bertambah akan memperbesar jumlah tenaga kerja dan penambahan tersebut memungkinkan suatu daerah untuk menambah produk. Namun akibat buruk dari penambahan penduduk yang tidak diimbangi oleh kesempatan kerja akan menyebabkan pertumbuhan ekonomi tidak sejalan dengan peningkatan kesejahteraan.

Jumlah tenaga kerja yang terserap di Kota Makassar selama sepuluh tahun terakhir dari tahun 2004-2013 mengalami fluktuasi, hal ini ditandai dengan 
Jurnal Ekonomi Balance Fakultas Ekonomi Dan Bisnis

Volume 11 No 1 Tahun 2015

berfluktuasinya angka kesempatan kerja. Pada tahun 2004 jumlah tenaga kerja sebanyak 404,546 jiwa dan menurun menjadi 389,155 jiwa pada tahun 2005. Pada tahun 2006 kembali meningkat menjadi 434,924 jiwa dan menurun lagi pada tahun 2007 menjadi 431,981 jiwa. Selanjutnya pada tahun 2008 meningkat sebanyak 498,653 jiwa dan menurun pada tahun 2009 menjadi 470,909. Demikian pada tahun 2010 dan 2011 mengalami peningkatan masing-masing sebesar 506,992 jiwa dan 541,668 jiwa. Pada tahun 2012 mengalami penurunan menjadi 514,556 jiwa dan kembali meningkat pada tahun 2013 menjadi 527,765 jiwa.

\section{LANDASAN TEORI}

Sukirno (2011) mengemukakan bahwa pertumbuhan ekonomi diartikan sebagai perkembangan kegiatan dalam perekonomian yang menyebabkan barang dan jasa yang diproduksi dalam masyarakat bertambah dan kemakmuran masyarakat meningkat. Jadi pertumbuhan ekonomi mengukur prestasi dari perkembangan suatu perekonomian dari suatu periode keperiode lainnya. Kemampuan suatu negara untuk menghasilkan barang dan jasa akan meningkat. Kemampuan yang meningkat ini disebabkan oleh pertambahan faktor-faktor produksi baik dalam jumlah dan kualitasnya. Investasi akan menambah barang modal dan teknologi yang akan digunakan juga makin berkembang. Di samping itu, tenaga kerja bertambah sebagai akibat perkembangan penduduk seiring dengan meningkatnya pendidikan dan keterampilan mereka.

\section{Teori Pertumbuhan Ekonomi Klasik}

Teori pertumbuhan ekonomi klasik dikemukakan oleh tokohtokohekonomi seperti Adam Smith, David Ricardo, Malthus, dan John Stuart Mill yang menyatakan bahwa pertumbuhan ekonomi dipengaruhi oleh empat faktor yaitu: luas tanah, jumlah penduduk, jumlah barang dan modal, dan teknologi yang digunakan. Menurut Smithdalam Arsyad (2015) unsur pokok dari sistem produksi suatu negara bergantung pada faktor-faktor berikut:

a. Sumber daya alam yang tersedia merupakan wadah paling mendasar dari kegiatan produksi suatu masyarakat dimana jumlah sumber daya alam yang tersedia mempunyai batas maksimum bagi pertumbuhan perekonomian;

b. Sumber daya manusia (jumlah penduduk dan tenaga kerja) merupakan peran positif dalam proses pertumbuhan output, maksudnya jumlah penduduk akan menyesuaikan dengan kebutuhan akan tenaga kerja dari suatu masyarakat. 
Jurnal Ekonomi Balance Fakultas Ekonomi Dan Bisnis

Volume 11 No 1 Tahun 2015

c. Akumulasi modal yang dimiliki memegang peranan penting dalam pembangunan ekonomi. Stok modal dapat diidentikan sebagai dana pembangunan dimana cepat lambatnya pembangunan ekonomi tergantung pada dana pembangunan tersebut.

Menurut Sukirno (2011) Laju pertumbuhan ekonomi sangat dipengaruhi oleh produktivitas sektor-sektor dalam menggunakan faktor-faktor produksinya. Produktivitas dapat ditingkatkan melalui berbagai sarana misalnya melalui pendidikan, pelatihan dan manajemen yang lebih baik.

\section{Teori Pertumbuhan Ekonomi Neo Klasik}

Sukirno (2011) pertumbuhan ekonomi bergantung kepada perkembangan faktor-faktor produksi. Pandangan ini dapat dinyatakan dalam persamaan sebagai berikut;

$$
\Delta \mathrm{Y}=\mathrm{f}(\Delta \mathrm{K}, \Delta \mathrm{L}, \Delta \mathrm{T})
$$

Dimana :

$$
\begin{aligned}
\Delta \mathrm{Y} & =\text { Tingkat pertumbuhan ekonomi } \\
\Delta \mathrm{K} & =\text { Tingkat pertumbuhan barang modal } \\
\Delta \mathrm{L} & =\text { Tingkat pertumbuhan tenaga kerja } \\
\Delta \mathrm{T} & =\text { Tingkat perkembangan teknologi }
\end{aligned}
$$

Faktor terpenting yang mewujudkan pertumbuhan ekonomi bukanlah pertambahan modal dan pertambahan tenaga kerja. Faktor terpenting adalah kemajuan teknologi dan pertumbuhan kemahiran dan kepakaran tenaga kerja.

\section{Konsep Dasar Pembangunan Ekonomi}

Sukirno (2011), pembangunan ekonomi adalah pertumbuhan ekonomi yang diikuti oleh perubahan dalam struktur dan kegiatan ekonomi. Perubahan dalam kegiatan ekonomi seperti perkembangan pendidikan, perkembangan kemahiran tenaga kerja, perbaikan teknologi dan kenaikan dalam taraf kemakmuran masyarakat. Pembangunan ekonomi hanya berlaku apabila pendapatan perkapita mengalami kenaikan secara berkepanjangan

\section{Pengertian Pembangunan Ekonomi Daerah}

Pembangunan ekonomi daerah menurut Arsyad (2015) adalah suatu proses yang mencakup pembentukan institusi-institusi baru, pembangunan industri-industri alternatif, perbaikan kapasitas kerja yang ada untuk 
Jurnal Ekonomi Balance Fakultas Ekonomi Dan Bisnis

Volume 11 No 1 Tahun 2015

menghasilkan produk dan jasa yang lebih baik, indikasi pasar-pasar baru, alih ilmu pengetahuan dan pengembangan perusahaan-perusahaan baru.

\section{Produk Domestik Bruto (PDB)}

Sukirno (2011) produk domestik bruto merupakan nilai barang dan jasa yang diproduksikan dalam suatu negara dengan menggunakan faktor-faktor produksi yang dimiliki oleh penduduk negara dan penduduk/perusahaan negara lain. Sukirno (2011) mengemukakan rumus perhitungan pertumbuhan ekonomi sebagai berikut :

$$
\Delta \mathrm{PDB}=\underline{\left(\mathrm{PDB}_{\mathrm{t}}-\mathrm{PDB}_{\mathrm{t}-1}\right)}
$$

$$
\mathrm{PDB}_{\mathrm{t}-1}
$$

Dimana :

$$
\begin{aligned}
& \triangle \mathrm{PDB}=\text { Pertumbuhan ekonomi atas dasar perubahan PDB (\%) } \\
& \mathrm{PDB}_{\mathrm{t}}=\text { Nilai PDB tahun } \mathrm{t} \\
& \mathrm{PDB}_{\mathrm{t}-1}=\text { Nilai } \mathrm{PDB} \text { tahun sebelumnya. }
\end{aligned}
$$

\section{METODE PENELITIAN}

Penelitian ini dilakukan di Kota Makassar. Jenis data yang digunakan dalam penelitian ini adalah data sekunder. Data tersebut kemudian diolah dengan menggunakan program computer yakni SPSS 16 dengan metode analisis regresi linear berganda. regresi linear berganda adalah sebagai berikut:

$$
Y=\beta 0+\beta_{1} X_{1}+\beta_{2} X_{2}+\beta_{3} X_{3}+\epsilon
$$

(sumber Sugiyono, 2012)

\section{Dimana :}

$$
\begin{aligned}
\mathrm{Y} & =\text { Pertumbuhan ekonomi } \\
\beta 0 & =\text { Nilai konstanta } \\
\mathrm{X}_{1} & =\text { Tenaga kerja } \\
\mathrm{X}_{2} & =\text { Tingkat pendidikan } \\
\mathrm{X}_{3} & =\text { Pengeluaran pemerintah } \\
\beta_{1} \beta_{2} \beta_{3} & =\text { Nilai koefisien regresi } \\
\in & =\text { Standar eror }
\end{aligned}
$$


Jurnal Ekonomi Balance Fakultas Ekonomi Dan Bisnis

Volume 11 No 1 Tahun 2015

PEMBAHASAN DAN HASIL

Struktur Ekonomi Kota Makassar Tahun 2004-2013 (Dalam Persen)

\begin{tabular}{|l|l|l|l|l|l|}
\hline Lapangan usaha & 2004 & 2005 & 2006 & 2007 & 2008 \\
\hline 1. Pertanian & 1,15 & 1,13 & 1,11 & 0,98 & 0,90 \\
\hline 2. Pertambangan \& Penggalian & 0,01 & 0,01 & 0,01 & 0,01 & 0,01 \\
\hline 3. Industri Pengolahan & 23,85 & 23,86 & 23,50 & 23,13 & 22,24 \\
\hline 4. Listrik, Gas, \& Air Bersih & 1,94 & 2,14 & 2,05 & 2,00 & 1,93 \\
\hline 5. Bangunan & 7,65 & 7,59 & 7,54 & 7,70 & 8,09 \\
\hline 6. Perdag, Hotel \& Restoran & 28,95 & 28,78 & 28,21 & 28,44 & 29,05 \\
\hline 7. Angkutan \& Komunikasi & 15,25 & 16,01 & 15,80 & 15,78 & 14,80 \\
\hline $\begin{array}{l}\text { 8. Keuangan, Sewa \& Jasa } \\
\text { Prsh }\end{array}$ & 9,97 & 9,63 & 10,09 & 10,37 & 10,09 \\
\hline 9. Jasa-Jasa & 11,23 & 10,85 & 11,69 & 16.59 & 12,89 \\
\hline
\end{tabular}

Sumber : BPS Kota Makassar, diolah dari beberapa sumber

Struktur Ekonomi Kota Makassar Tahun 2004-2013 (Dalam Persen)

\begin{tabular}{|c|c|c|c|c|c|}
\hline Lapangan usaha & 2009 & 2010 & 2011 & 2012 & 2013 \\
\hline 1. Pertanian & 0,82 & 0,74 & 0,67 & 0,59 & 0,55 \\
\hline $\begin{array}{l}\text { 2. Pertambangan \& } \\
\text { Penggalian }\end{array}$ & 0,01 & 0,01 & 0,00 & 0,00 & 0,00 \\
\hline 3. Industri Pengolahan & 20,74 & 19,69 & 18,90 & 17,83 & 17,11 \\
\hline 4. Listrik, Gas, \& Air Bersih & 1,79 & 1,81 & 1,76 & 1,71 & 1,66 \\
\hline 5. Bangunan & 7,49 & 7,83 & 7,73 & 7,59 & 7,86 \\
\hline 6. Perdag, Hotel \& Restoran & 28,70 & 29,08 & 29,43 & 29,36 & 29,38 \\
\hline 7. Angkutan \& Komunikasi & 13,93 & 14,33 & 14,36 & 15,24 & 15,28 \\
\hline $\begin{array}{l}\text { 8. Keuangan, Sewa \& Jasa } \\
\text { Prsh }\end{array}$ & 10,17 & 10,25 & 10,85 & 11,23 & 12,07 \\
\hline 9. Jasa-Jasa & 15,88 & 16,26 & 16,31 & 16,37 & 16,09 \\
\hline
\end{tabular}

Sumber : BPS Kota Makassar, diolah dari beberapa sumber

Menunjukkan bahwa perekonomian Kota Makassar dapat dikatakan relatif mapan karena keadaan struktur ekonominya lebih bertumpu kepada sektor tersier. Menurut Badan Pusat Statistik (2013) Pergeseran struktur ekonomi suatu wilayah dapat dilihat dari perubahan peranan masing-masing sektor kegiatan ekonomi pada kurun waktu tersebut. Apabila kondisi struktur ekonomi suatu 
Jurnal Ekonomi Balance Fakultas Ekonomi Dan Bisnis

Volume 11 No 1 Tahun 2015

wilayah sudah mapan, perubahan peranan sektor-sektor kegiatan ekonominya biasanya tidak terlalu besar. Sementara pada kondisi struktur ekonomi yang belum mapan, perubahannya lebih berfluktuasi dibanding wilayah yang sudah mapan. Struktur ekonomi Kota Makassar dalam kurun waktu tahun 2004-2013 nampak membaik, hal ini disebabkan menurunnya peranan sektor pertanian, penggalian, industri, listrik serta meningkatnya sektor perdagangan, angkutan dan komunikasi, dan keuangan pada pembentukan PDRB Kota Makassar.

PDRB Atas Harga Konstan Dan Pertumbuhan Ekonomi

Kota Makassar Tahun 2009-2013

\begin{tabular}{|l|l|l|}
\hline Tahun & $\begin{array}{l}\text { PDRB Harga Konstan } \\
\text { (Juta Rupiah) }\end{array}$ & $\begin{array}{l}\text { Pertumbuhan Ekonomi } \\
(\%)\end{array}$ \\
\hline 2004 & 978533389 & 10,17 \\
\hline 2005 & 1049254067 & 7,22 \\
\hline 2006 & 1134184821 & 8,09 \\
\hline 2007 & 1226153892 & 8,11 \\
\hline 2008 & 1356182718 & 10,60 \\
\hline 2009 & 1479818768 & 9,12 \\
\hline 2010 & 1625245143 & 9,83 \\
\hline 2011 & 1782069797 & 9,65 \\
\hline 2012 & 1958206039 & 9,88 \\
\hline 2013 & 2132722788 & 8,91 \\
\hline
\end{tabular}

Sumber : BPS Kota Makassar, diolah dari berbagai sumber.

Menunjukkan pertumbuhan ekonomi yang dicapai kota Makassar pada tahun 2004-2013. Pada tahun 2004 pertumbuhan ekonomi Kota Makassar sebesar 10,17\% dan menurun pada tahun 2005 sebesar 7,22\%. Pada tahun 2006 mengalami peningkatan sebesar 8,09\% dan menurun pada tahun 2009 sebesar 9,12\%. Pada tahun 2011 pertumbuhan ekonomi sebesar 9,65\% sedikit melambat dari tahun sebelumnya dan mengalami kenaikan pada tahun 2012 sebesar 9,88\%. Pada tahun 2013 pertumbuhan ekonomi Kota Makassar sebesar 
Jurnal Ekonomi Balance Fakultas Ekonomi Dan Bisnis

Volume 11 No 1 Tahun 2015

8,91\% sedikit melambat dibandingkan tahun sebelumnya, namun PDRB dari tahun ke tahun mengalami peningkatan yang semakin membaik.

Jumlah Tenaga Kerja Di Kota Makassar Tahun 2004-2013

\begin{tabular}{|l|l|}
\hline Tahun & Jumlah Tenaga Kerja \\
\hline 1 & 2 \\
\hline 2004 & 404546 \\
\hline 2005 & 389155 \\
\hline 2006 & 434924 \\
\hline 1 & 2 \\
\hline 2007 & 431981 \\
\hline 2008 & 498653 \\
\hline 2009 & 470909 \\
\hline 2010 & 506992 \\
\hline 2011 & 541668 \\
\hline 2012 & 514556 \\
\hline 2013 & 527765 \\
\hline
\end{tabular}

Sumber : BPS Kota Makassar, diolah dari beberapa sumber

Data penelitian

\begin{tabular}{|l|l|l|l|l|}
\hline Tahun & Y & X1 & X2 & X3 \\
\hline 2004 & 978533389 & 404546 & 450428 & 560513319 \\
\hline 2005 & 1049254067 & 389155 & 457635 & 608909469 \\
\hline 2006 & 1134184821 & 434924 & 457193 & 829478742 \\
\hline 2007 & 1226153892 & 431981 & 469327 & 1016955301 \\
\hline 2008 & 1356182718 & 498653 & 475650 & 1225077157 \\
\hline 2009 & 1479818768 & 470909 & 497400 & 1325111876 \\
\hline 2010 & 1625245143 & 506992 & 586703 & 1534709976 \\
\hline 2011 & 1782069797 & 541668 & 586703 & 1589355783 \\
\hline 2012 & 1958206039 & 514556 & 559119 & 2213547065 \\
\hline 2013 & 2132722788 & 527765 & 568341 & 2091629062 \\
\hline
\end{tabular}

Sumber : Data diolah dari BPS Kota Makassar berbagai tahun terbitan

Keterangan : $\mathrm{Y}=$ Pertumbuhan Ekonomi (PDRB Juta Rupiah)

$$
\begin{aligned}
& \text { X1 = Jumlah Tenaga Kerja ( Satuan Orang) } \\
& \text { X2 = Tingkat Pendidikan ( Tamatan SLTA \& Perguruan Tinggi) } \\
& \text { X3 = Total Pengeluaran Pemerintah ( Juta Rupiah ) }
\end{aligned}
$$


Jurnal Ekonomi Balance Fakultas Ekonomi Dan Bisnis

Volume 11 No 1 Tahun 2015

Hasil Log Dari Data Penelitian

\begin{tabular}{|l|l|l|l|l|}
\hline Tahun & Y & X1 & X2 & X3 \\
\hline 2004 & 8,99 & 5,61 & 5.65 & 8,74 \\
\hline 2005 & 9,02 & 5,59 & 5.66 & 8,87 \\
\hline 2006 & 9,05 & 5,63 & 5.66 & 8,94 \\
\hline 2007 & 9,09 & 5,64 & 5.67 & 9,01 \\
\hline 2008 & 9,13 & 5,69 & 5.67 & 9,09 \\
\hline 2009 & 9,16 & 5,67 & 5.68 & 9,12 \\
\hline 2010 & 9,21 & 5,70 & 5.76 & 9,18 \\
\hline 2011 & 9,25 & 5,73 & 5.76 & 9,20 \\
\hline 2012 & 9,29 & 5,71 & 5.74 & 9,34 \\
\hline 2013 & 9,32 & 5,72 & 5.75 & 9,32 \\
\hline
\end{tabular}

Sumber : Hasil olahan dengan SPSS 16

Dalam penelitian ini data diubah dalam bentuk log karena data penelitian memiliki tingkat perbedaan yang tinggi.

Rangkuman Hasil Analisis Variabel

\begin{tabular}{|l|l|l|l|l|l|}
\hline \multirow{2}{*}{ Variabel } & \multirow{2}{*}{ Koefisien } & Sig & \multirow{2}{*}{ Beta } & Colinearity statistics \\
\cline { 4 - 6 } & & & & Tolerance & VIF \\
\hline X1 & 0,105 & 0,823 & 0,045 & 0,095 & 10,479 \\
\hline X3 & 0,734 & 0,048 & 0,295 & 0,245 & 4,085 \\
\hline $\begin{array}{l}\text { Konstanta }=1,698 \\
\text { F(sig) }=0,00 \\
\text { R }=0,990, \text { R Square }=0,979 \\
\text { Durbin Waston }=1,609 \\
\text { F tabel }=4,757, \text { T tabel }=2,446\end{array}$ & 0,004 & 0,772 & 0,114 & 8,734 \\
\hline
\end{tabular}

Sumber : Hasil Olahan SPSS16.0

Berdasarkan hasil rangkuman analisis, maka diperoleh persamaan regresi sebagai berikut:

$Y=1,698+0,105 X 1+0,734 X 2+0,426 X 3$ 
Jurnal Ekonomi Balance Fakultas Ekonomi Dan Bisnis

Volume 11 No 1 Tahun 2015

Persamaan regresi tersebut dapat dijelaskan sebagai berikut:

a) Konstanta sebesar 1,698 artinya jika jumlah tenaga kerja, tingkat pendidikan dan pengeluaran pemerintah nilainya berada pada titik 0 , maka nilai pertumbuhan ekonomi akan berada pada level 1,698.

b) Koefisien regresi variabel jumlah tenaga kerja (X1) yaitu sebesar 0,105 artinya bahwa setiap peningkatan jumlah tenaga kerja sebesar satu satuan, maka akan menyebabkan pertumbuhan ekonomi Kota Makassar meningkat sebesar 0,105 satuan, ceteris paribus.

c) Koefisien regresi variabel tingkat pendidikan (X2) yaitu sebesar 0,734 artinya bahwa setiap peningkatan tingkat pendididkan sebesar 1 satuan, maka akan menyebabkan pertumbuhan ekonomi Kota Makassar meningkat sebesar 0,734 satuan, ceteris paribus.

d) Koefisien regresi variabel pengeluaran pemerintah (X3) yaitu sebesar 0,426artinya bahwa setiap peningkatan pengeluaran pemerintah sebesar 1 satuan, maka akan menyebabkan pertumbuhan ekonomi Kota Makassar meningkat sebesar 0,426 satuan, ceteris paribus. 
Jurnal Ekonomi Balance Fakultas Ekonomi Dan Bisnis

Volume 11 No 1 Tahun 2015

\section{PENUTUP}

\section{SIMPULAN}

1. Besarnya nilai $R$ Square $\left(R^{2}\right)$ adalah 0,979 atau $97,9 \%$. Artinya besarnya pengaruh variabel independent yaitu jumlah tenaga kerja, tingkat pendidikan dan pengeluaran pemerintah terhadap variabel dependent yaitu pertumbuhan ekonomi sebesar $97,9 \%$. Sedangkan sisanya sebesar 2,1\% dijelaskan atau dipengaruhi oleh variabel lain yang tidak diteliti dalam penelitian ini. Jumlah tenaga kerja memiliki hubungan yang positif namun tidak signifikan terhadap pertumbuhan ekonomi di Kota Makassar selama periode 2004-2013. Hal ini dibuktikan dari nilai $t$ hitung lebih kecil dari t tabel yaitu 0,274 $<2,446$ yang artinya Ho ditolak atau secara parsial tidak ada pengaruh signifikan antara jumlah tenaga kerja terhadap pertumbuhan ekonomi di Kota Makassar.

2. Tingkat pendidikan memiliki hubungan yang positif dan signifikan terhadap pertumbuhan ekonomi di Kota Makassar selama periode 2004-2013. Hal ini dibuktikan dengan nilai $t$ hitung lebih besar dari t tabel yaitu 2,476 $>2,446$ yang artinya Ho diterima atau secara parsial ada pengaruh signifikan antara tingkat pendidikan terhadap pertumbuhan ekonomi di Kota makassar. Pengeluaran pemerintah memiliki hubungan yang positif dan signifikan terhadap pertumbuhan ekonomi di Kota Makassar selama periode 20042013. Hal ini dibuktikan dengan nilai $t$ hitung lebih besar dari $t$ tabel yaitu $4,431>2,446$ yang artinya Ho diterima atau secara parsial ada pengaruh signifikan antara pengeluaran pemerintah terhadap pertumbuhan ekonomi di Kota makassar.

3. Faktor yang berpengaruh dominan terhadap pertumbuhan ekonomi di Kota Makassar selama periode 2004-2013 adalah tingkat pendidikan karena nilai koefisien regresinya lebih besar lebih besar yaitu 0,734 dibandingkan dengan nilai koefisien regresi variabel independent lainnya.

\section{Saran}

Peningkatan kualitas tenaga kerja dapat dilakukan melalui pendidikan formal maupun non formal, dan dapat saja diselenggarakan oleh pemerintah maupun swasta. 
Jurnal Ekonomi Balance Fakultas Ekonomi Dan Bisnis

Volume 11 No 1 Tahun 2015

\section{DAFTAR PUSTAKA}

Anonim. Indikator Kesejahteraan Rakyat Kota Makassar,Berbagai Tahun Terbitan:Badan Pusat Statistik ProvinsiSulawesi Selatan.

.Indeks Pembangunan Manusia Kota Makassar, Berbagai Tahun Terbitan: Badan Pusat Statistik ProvinsiSulawesi Selatan.

- Makassar Dalam Angka, Berbagai Tahun Terbitan: Badan Pusat Statistik ProvinsiSulawesi Selatan.

.Produk Domestik Regional Bruto Kota Makassar, Berbagai Tahun Terbitan: Badan Pusat Statistik ProvinsiSulawesi Selatan. . Statistik Keuangan Pemerintah Kabupaten/Kota, Berbagai Tahun Terbitan: Badan Pusat Statistik Sulawesi Selatan. . Statistik Daerah Kota Makassar, Berbagai Tahun Terbitan: Badan Pusat Statistik Sulawesi Selatan.

Arsyad, Lincolin. 2015. Ekonomi pembangunan. Edisikelima: UPP STIE YKPN Yogyakarta

Dumairy, 2006. Perekonomian Indonesia. Jakarta: Erlangga.

Kuncoro, Mudrajat. 2003. Ekonomi Pembangunan: Teori, Masalah Dan Kebijakan: UUP AMP YKPN Yogyakarta.

Mankiw, N.Gregory. 2003. Teori Makro Ekonomi.Ed.5, Jakarta: Penerbit Erlangga.

Mangkoesbroto, gurithno. 2002. Ekonomi publik. Yogyakarta: BPFE.

Sugiyono. 2012. Metode penelitian kuantitatif kualitatif dan R\& D. Bandung: CV. Alvabeta.

Sukirno, sadono. 2000. Makroekonomi Modern: Perkembangan Pemikiran Dari Klasik Hingga Keynesian Baru: Raja Grafinda Pustaka.

. 2011. Teori pengantar makroekonomi. Edisi ketiga :Penerbit P.T. Raja Grafindo Persada.

Todaro, Micheal dan Stephen Smith. 2003. Pembangunan Ekonomi Di Dunia Ketiga, edisi ke 8, Jakarta: Erlangga. 